\title{
Effectiveness of Using Folklore Text-Based Learning Media Literacy in Class X Students of MAN Tg. Pura
}

\author{
Ahmad Drani ${ }^{1}$, Abdurahman Adisaputera ${ }^{2}$, Elly Prihasti Wuriyani ${ }^{3}$ \\ ${ }^{1,2,3}$ Universitas Negeri Medan, Indonesia \\ ahmaddrani58@gmail.com
}

\section{Abstract}

This developmental research aimed to analyze the Effectiveness of Using Folklore Text-Based Learning Media Literacy in Class X Students of MANTg. Pura. This research was conducted at MAN $2 \mathrm{Tg}$ Pura in class $X$ students. The implementation of this research is planned to be carried out in February 2019 to April 2019. The data in this study are the results of observations, interviews, material validation questionnaires and learning media design, perception questionnaire results. teachers of the learning media developed, as well as student learning outcomes, amounting to 35 people. The observation data in the form of the value of learning to write saga text totaling 35 students sofar and the results of interviews in the form of the opinions of 2 Indonesian language teachers regarding learning to write folklore texts (saga) were obtained from Indonesian students and teachers. Data in the form of material validation and learning media design were obtained from the validator/team of experts, as well as data on learning outcomes from students before and after using the developed learning media. The results of students' learning ability in writing literacy-based folklore texts after using the developed learning media were in the "very good" category with an average value of 81.14 and the average value before using literacy-based folklore text learning media of 66, 57 which is in the "good" category. This proves that student learning outcomes are higher after using literacy-based folklore text learning media with a significance difference of $14.57 \%$.
Keywords folklore text-based; literacy; learning media

\section{Introduction}

Folk stories in society need not be doubted anymore considering the importance of the values contained in them. In this connection, education is one of the most important elements, especially in maintaining the complexity and existence of existing cultures. Because education creates strong human resources who are able to make changes towards the development of a more advanced nation and state. In addition, education can form humans who are able to use technology and are able to use thinking power without leaving the values of the national personality, essential human norms, norms of tradition, culture, and religious norms. The challenges facing the world of education in today's global era show increasingly fast and complex intensity, this will clearly have a major impact on the delivery of education in schools. In line with that, learning requires a variety of special approaches such as applying an intellectual, imaginative, creative, productive, collaborative, competitive and technological approach. Efforts to introduce the results of folklore which are very important in the Indonesian language so that they are known and belong to all Indonesian people. 
The activity of writing and introducing folk tales to students is a very productive effort, namely in the sense of donating valuable ancestral inheritances, meaning that it can foster a healthy and rich new Indonesian culture. In line with the development of science and technology, the use of media in literacy-based learning is a necessity in order to achieve learning objectives. One of the causes of the unsuccessfulness of the learning process is the lack of use of instructional media, both those available in schools and those deliberately designed by the teacher. Technology in the era of globalization is developing very rapidly. So that advances in information technology can be used to make an introduction application to learning material, especially folklore, namely saga. Teachers are required to develop learning materials with information technology, so that they do not want a teacher to develop their knowledge and skills in processing material into media supported by information technology, both in the form of networks and software. Likewise with educators who are in the MAN 2 Tg Pura school.

\section{Review of Literatures}

\subsection{Learning to Write}

Tarigan (2013: 1) states that Indonesian language learning has four components of language skills, namely listening, reading, writing and speaking skills. One of the four language skills taught is writing. Writing is essentially an orderly process of thinking, so that what is written is easy for readers to understand. A writing is said to be good if it has characteristics, including meaningful, clear, round and whole, economical and fulfills grammatical rules.

Learning to write is a process of expressing ideas or thoughts in written form. Writing can be defined through various points of view. In the corner At its simplest, writing can be defined as a process produces a sound symbol. This kind of writing is known as write a start. At the next stage writing can be more complex. Writing is basically a process for coming up with ideas and ideas in written language.

In line with this, Soebachman (2014: 27) argues that writing is a medium of our communication with other people. A media to convey what we want, spread what we think, and invite other people and lead them to think and develop. Soebachman (2014: 85) also argues that writing is a process of producing writing containing ideas. The opinion in line with Akhadiah (in Syamsuyurnita, 2012: 1) views writing is a language communication activity that uses writing as the medium. Writing as a thought process means that before and or after putting ideas and feelings in writing, it requires the involvement of the thinking process.

In the writer's point of view, writing can also be said as an activity react means writing is the process of expressing opinions on the basis input obtained by the author from various available sources of ideas. Source an idea can be any object capable of stimulating the writer to writing includes other writings that have been produced by others. In relation to other people's writing that encourages someone to write, the writing it produces is known as reproduction writing. Write too defined as the activity of generating messages in the social dimension and for a specific purpose. Writing in this case is interpreted as creating activity meaning related to the development of individual abilities in understand the socio-cultural context in which the writing was written. Write with another word is the ability to understand the socio-cultural context of the community. 


\subsection{The Nature of Folklore}

Literary work is one of the works of art literature which is also part of culture. As a result of art, literary works contain elements of beauty that can cause feelings of joy, pleasure, emotion, attracting attention and refreshing the audience. There are many ideas about the value of character in literary works, for example in folklore. In essence,Folklore is a national cultural heritage and has values that can be developed and utilized for presentday life to the future, among others in relation to literary appreciation. Folklore has long been born as a vehicle for understanding and ideas as well as the inheritance of values that grow in society. In fact, folklore has for centuries served as the basis of communication between creators and society, in the sense that creation is based on oral and is easier to replace because there are elements that are known to society.

Other than that folklore is part of the history and culture of a nation. In general, folklore tells about the occurrence of various things, such as the occurrence of the universe, place, or an important event. Folklore is part of the cultural and historical wealth possessed by the Indonesian nation. In general, folk tales tell about an event in a place or the origin of a place. The characters that appear in folklore are generally manifested in the form of animals, humans and gods. The function of folklore apart from being entertainment, can also be used as role models, especially folk tales that contain messages of moral education

The prose that developed in the era of animism-dynamism is a form of folklore. Many experts have tried to define and express the meaning of folklore, including Rismawati (2017: 19) folklore is one of the old literary works that was passed down orally which contains events that may occur or are just imagination and are a description of the people who own them. Folklore is found in all tribes in Indonesia. Its contents reveal not only surface matters, but also the joints of life in a deeper way. According to Marsellaa and Putri (2020) In fact, the folklore contains a lot of structured messages and messages conveyed implicitly.

\subsection{The Nature of Literacy}

Literacy is synonymous with reading and writing, but according to the Prague Declaration in 2013, it explains that literacy includes how to communicate in society. Based on this initial scope, literacy is seen as a condition of literacy, word literacy and meaning literacy. Implicitly, literacy was only about reading and writing. According to Abidin, (2015: 49) Literacy is used to use language and images in rich and varied forms to read, write, listen, speak, see, present and think critically about ideas. While Gray in Hamilton (2005: 9).

'Functional literacy' has been defined as follows: A person is literate when he [sic] has acquired the essential knowledge and skills which enable him to engage in all those activities in which literacy is required for effective functioning in his group and community, and whose attainments in reading, writing and arithmetic make it possible for him to continue to use these skills towards his own and the community's development.

A person is literate when he has acquired essential knowledge and skills which enable him to engage in all activities in which literacy is necessary to function effectively in his group and society, and whose attainment in reading leads him to write and make arithmetic. Perhaps he continues to use these skills towards his own development and society. According to Yohana et al (2019) Literacy reading in the world of higher education is a collection of skills that are generic and can be applied in all fields of 
science. According to Nainggolan and Rosliana (2020) Literacy development needs to occur in learning in all subjects to optimize higher order thinking skills.

\subsection{Characteris tics of Interactive Multimedia}

Gerlach \& Ely (through Azhar Arsyad, 2009: 12) suggest three characteristics of media, namely having fixative property, manipulative property, and distributive property. Having a fixative property, describing the media can record, store, preserve and reconstruct an event or object and in addition, it can allow a recording of events or objects that occur at a certain time to be transported regardless of time. Has manipulative characteristics (manipulative property), manipulative characteristics, namely the media can accelerate or slow down presenting an event to students. Has a distributive property, Distributive characteristics mean that the media can allow an object or event to be transported through space and simultaneously the event is presented to a large number of learners with a relatively similar experiential stimulus about that event.

Five kinds of interactive multimedia characteristics when compared with other media, namely flexible, self-pacing, content-rich, interactive, and individual (Hackbarth, 1996: 228). Flexible, both in providing the opportunity to choose the content of each subject presented, as well as the variety and placement for access. Besides that, it is flexible in its use which can be used in class, individually or in small groups. The flexibility of using time is also a prominent feature so it can be suitable for everyone. Selfpacing is serving individual learning speed, meaning that the speed at which it is used is very important to the ability and readiness of each student who uses it. Students who are fast are given the opportunity to spur their learning speed as optimally as possible, on the other hand, those who are slow are also given the opportunity to repeat and learn more time greetings.

\subsection{Adobe Flash Professional CS6}

Flash is one of the animation software released by Macromedia which has now been adopted by Adobe, Inc. Adobe Flash Professional CS6 is a version of Adobe Flash that has been updated from previous versions, namely Adobe Flash CS3 Professional, Adobe Flash CS4 Professional, and Adobe Flash Professional CS5.

Island Script (in Fatimah, 2016: 23-24) says that Adobe Flash Professional CS6 is an animated graphic software that can create graphic objects and animate them so that we can immediately create design objects without having to use supporting graphic software such as Illustrator or Photoshop. Adobe Flash Professional CS6 is equipped with several features that are not owned by previous versions of Adobe Flash, such as the bone tool which functions to create reinforcement animations by adding joint points to objects, the 3D Rotation tool which functions to perform 3D rotation of objects based on the $\mathrm{X}, \mathrm{Y}$ axes, and $\mathrm{Z}$, as well as changes to the layout of the panels that make it easier for users to operate.

\subsection{Definition of Learning Outcomes}

A person is said to have learned, if he can do something that could not be done before. Learning is a process within individuals who interact with the environment to get changes in behavior, namely changes in cognitive, affective, and psychomotor aspects (Purwanto, 2009: 38). Learning outcomes can be explained by understanding the two words that make up it, namely "results" and "learning". The definition of results (product) indicates an acquisition as a result of carrying out an activity or process that results in a 
functional change in input. Production results are gains obtained because of the activity of converting raw materials into finished goods (Purwanto, 2009: 44).

\section{Research Methods}

This research was conducted at MAN $2 \mathrm{Tg}$ Pura in class $\mathrm{X}$ students. The implementation of this research is planned to be carried out in February 2019 to April 2019. The data in this study are the results of observations, interviews, material validation questionnaires and learning media design, perception questionnaire results. teachers of the learning media developed, as well as student learning outcomes, amounting to 35 people. The observation data in the form of the value of learning to write saga text totaling 35 students so far and the results of interviews in the form of the opinions of 2 Indonesian language teachers regarding learning to write folklore texts (saga) were obtained from Indonesian students and teachers. Data in the form of material validation and learning media design were obtained from the validator / team of experts, as well as data on learning outcomes from students before and after using the developed learning media.

\section{Discussion}

In the testing phase of learning media, writing literacy-based folklore texts. Several test stages were carried out, namely individual tests, small group tests and limited field tests. Where each test is carried out in stages and improvements are made to each test for the sake of product perfection. The following will be described as follows.

Media testing was carried out on individual tests carried out on class $\mathrm{X}$ students of MAN $2 \mathrm{Tg}$. Pura. The purpose of the individual test is to identify deficiencies in the literacy-based learning media that has been developed.

Table 1. Results of Individual Trial Response Analysis

\begin{tabular}{|c|c|c|c|c|c|c|c|}
\hline \multirow{2}{*}{ No. } & \multirow{2}{*}{ Assessment Indicators } & \multicolumn{3}{|c|}{$\begin{array}{l}\text { Responde } \\
\text { nts }\end{array}$} & \multirow{3}{*}{$\begin{array}{l}\text { Total } \\
\text { score }\end{array}$} & \multirow{3}{*}{$\%$} & \multirow{3}{*}{ Criteria } \\
\hline & & \multirow{2}{*}{1} & \multirow[b]{2}{*}{2} & \multirow{2}{*}{3} & & & \\
\hline & $\begin{array}{c}\text { Quality of Learning } \\
\text { Materials }\end{array}$ & & & & & & \\
\hline 1 & $\begin{array}{l}\text { Is the material being } \\
\text { taught easy for you to } \\
\text { understand }\end{array}$ & 3 & 3 & 4 & 10 & $83.3 \%$ & Very good \\
\hline 2 & $\begin{array}{l}\text { How is clarity regarding } \\
\text { the instructions in the } \\
\text { learning media used }\end{array}$ & 3 & 4 & 4 & 11 & $91.6 \%$ & Very good \\
\hline 3 & $\begin{array}{l}\text { Is it easy to understand } \\
\text { the sentences in the folk } \\
\text { story text can be } \\
\text { understood? }\end{array}$ & 3 & 3 & 3 & 9 & $75 \%$ & Good \\
\hline
\end{tabular}




\begin{tabular}{|c|c|c|c|c|c|c|c|}
\hline 4 & $\begin{array}{l}\text { How can it be easier to } \\
\text { understand folklore } \\
\text { material through the } \\
\text { media }\end{array}$ & 3 & 3 & 4 & 10 & $83.3 \%$ & Very good \\
\hline 5 & $\begin{array}{l}\text { How is it easier to } \\
\text { understand the content, } \\
\text { structure, language and } \\
\text { intrinsic value of folklore } \\
\text { through the media more } \\
\text { quickly }\end{array}$ & 3 & 3 & 3 & 9 & $75 \%$ & Good \\
\hline 6 & $\begin{array}{l}\text { How easy is it to } \\
\text { understand folklore } \\
\text { material through the } \\
\text { media }\end{array}$ & 4 & 4 & 3 & 11 & $91.6 \%$ & Very good \\
\hline 7 & $\begin{array}{l}\text { Is the order of presenting } \\
\text { folklore material in the } \\
\text { learning media right? }\end{array}$ & 3 & 4 & 4 & 11 & $91.6 \%$ & Very good \\
\hline 8 & $\begin{array}{l}\text { How is the completeness } \\
\text { of the training activities } \\
\text { in the learning media } \\
\text { appropriate }\end{array}$ & 3 & 4 & 4 & 11 & $91.6 \%$ & Very good \\
\hline 9 & $\begin{array}{l}\text { Does the clarity of the } \\
\text { learning media make you } \\
\text { more active (feedback) }\end{array}$ & 3 & 4 & 2 & 9 & $75 \%$ & Good \\
\hline 10 & $\begin{array}{l}\text { Does learning by using } \\
\text { programs in the media } \\
\text { make it easier for you to } \\
\text { understand the content of } \\
\text { folklore material during } \\
\text { learning activities }\end{array}$ & 4 & 3 & 3 & 10 & $83.3 \%$ & Very good \\
\hline \multicolumn{5}{|c|}{ Amount average } & 101 & 84.1 & Very good \\
\hline \multicolumn{2}{|r|}{$\begin{array}{c}\text { Technical / Appearance } \\
\text { Quality }\end{array}$} & & & & & & \\
\hline 11 & $\begin{array}{l}\text { How beautiful is the } \\
\text { display on the learning } \\
\text { media screen }\end{array}$ & 4 & 3 & 4 & 11 & $91.6 \%$ & Very good \\
\hline 12 & $\begin{array}{l}\text { How is the legibility of } \\
\text { the text of folklore in the } \\
\text { media? }\end{array}$ & 4 & 3 & 3 & 10 & $83.3 \%$ & Very good \\
\hline 13 & $\begin{array}{l}\text { What is the quality of } \\
\text { images, illustrations and } \\
\text { sound in the media. }\end{array}$ & 3 & 2 & 3 & 8 & $66.6 \%$ & Good \\
\hline 14 & $\begin{array}{l}\text { What is the quality of the } \\
\text { image color used in the } \\
\text { learning media }\end{array}$ & 3 & 3 & 3 & 9 & $75 \%$ & Good \\
\hline
\end{tabular}




\begin{tabular}{|c|l|c|c|c|c|c|c|}
15 & $\begin{array}{l}\text { How is the composition } \\
\text { of the combination of the } \\
\text { colors used in the media }\end{array}$ & 3 & 3 & 3 & 9 & $75 \%$ & Good \\
\hline 16 & $\begin{array}{l}\text { How easy is the } \\
\text { navigation in the media }\end{array}$ & 3 & 3 & 3 & 9 & $75 \%$ & Good \\
\hline 17 & $\begin{array}{l}\text { How is the use of } \\
\text { animation in the media }\end{array}$ & 3 & 2 & 3 & 8 & $66.6 \%$ & Good \\
\hline 18 & $\begin{array}{l}\text { Are you more interactive } \\
\text { with these media in } \\
\text { learning activities? }\end{array}$ & 3 & 4 & 3 & 10 & $83.3 \%$ & Very good \\
\hline \multicolumn{2}{|c|}{ Amount Average } & & $\mathbf{7 4}$ & $\mathbf{9 6}$ & Very good \\
\hline \multicolumn{2}{|c|}{ Amount Average } & $\mathbf{1 7 5}$ & $\mathbf{8 1 . 0 1}$ & Very good \\
\hline
\end{tabular}

The results of the test on learning media that were carried out by individual groups obtained an overall average of 81.01 with very good criteria. With the description of the question indicator, eighteen questions are loaded. The quality of the material obtained an average of 84.1 and the technical quality of the learning media was 96 , all of which were included in the very good criteria.
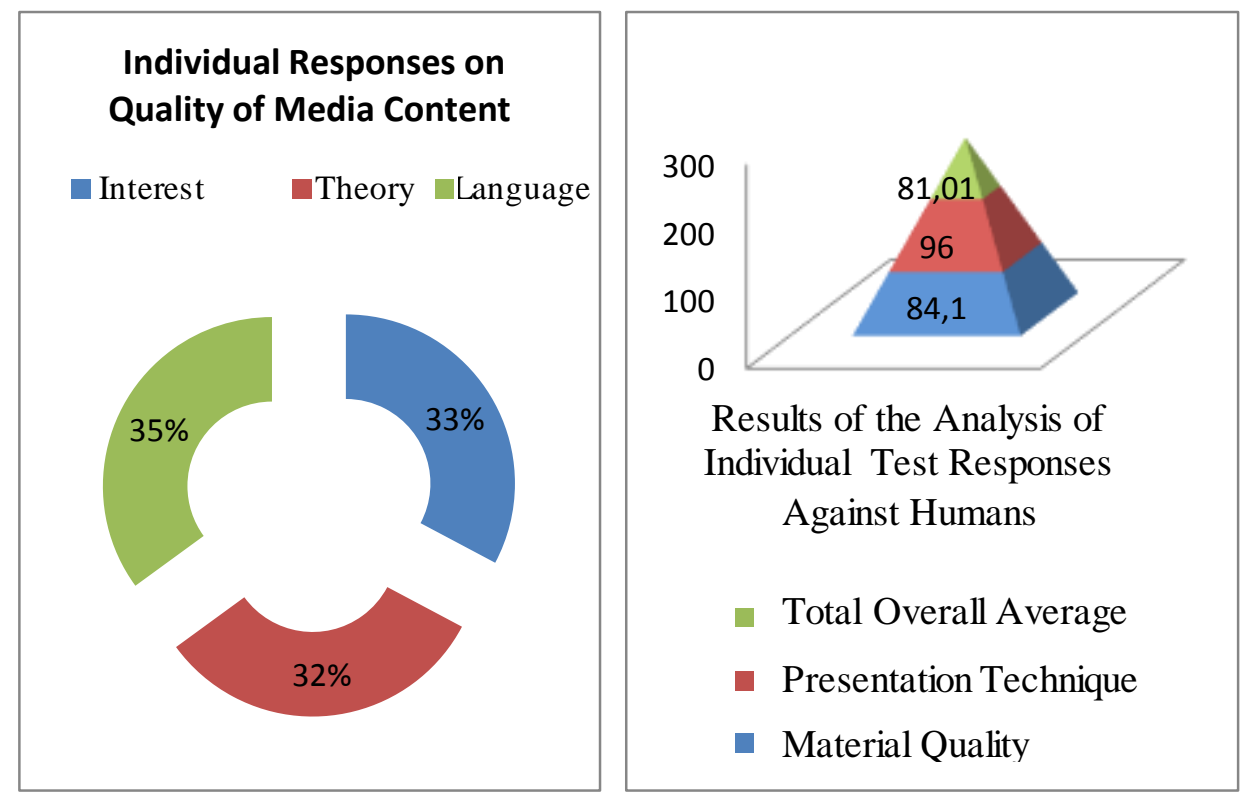

Figure 1. Responses to Individual Test Results Regarding the Quality of Content and Student Responses of Class XC MAN 2 Tg. Pura

This small group trial was tested by involving 9 students, namely 3 high achievers, 3 medium achievers, 3 low achievers. This small group trial result data is intended to find out some of the weaknesses or obstacles experienced when the product in the form of learning media is used. 
Table 2. Results of Small Group Test Response Analys is

\begin{tabular}{|c|c|c|c|c|}
\hline No. & Assessment Indicators & \multirow{2}{*}{$\begin{array}{l}\text { Total } \\
\text { score }\end{array}$} & \multirow[t]{2}{*}{$\%$} & \multirow[t]{2}{*}{ Criteria } \\
\hline \multicolumn{2}{|r|}{ Quality of Le arning Mate rials } & & & \\
\hline 1 & $\begin{array}{l}\text { Is the material being taught easy for you to } \\
\text { understand }\end{array}$ & 30 & $83.3 \%$ & $\begin{array}{l}\text { Very } \\
\text { good }\end{array}$ \\
\hline 2 & $\begin{array}{l}\text { How is clarity regarding the instructions in } \\
\text { the learning media used }\end{array}$ & 30 & $83.3 \%$ & $\begin{array}{l}\text { Very } \\
\text { good }\end{array}$ \\
\hline 3 & $\begin{array}{l}\text { Is it easy to understand the sentences in the } \\
\text { folk story text can be understood? }\end{array}$ & 27 & $75 \%$ & Good \\
\hline 4 & $\begin{array}{l}\text { How can it be easier to understand folklore } \\
\text { material through the media }\end{array}$ & 31 & $86.1 \%$ & $\begin{array}{l}\text { Very } \\
\text { good }\end{array}$ \\
\hline 5 & $\begin{array}{l}\text { How is it easier to understand the content, } \\
\text { structure, language and intrinsic value of } \\
\text { folklore through the media more quickly }\end{array}$ & 28 & $77.7 \%$ & Good \\
\hline 6 & $\begin{array}{l}\text { How easy is it to understand folklore } \\
\text { material through the media }\end{array}$ & 31 & $86.1 \%$ & $\begin{array}{l}\text { Very } \\
\text { good }\end{array}$ \\
\hline 7 & $\begin{array}{l}\text { Is the order of presenting folklore material } \\
\text { in the learning media right? }\end{array}$ & 32 & $88.8 \%$ & $\begin{array}{l}\text { Very } \\
\text { good }\end{array}$ \\
\hline 8 & $\begin{array}{l}\text { How is the completeness of the training } \\
\text { activities in the learning media appropriate }\end{array}$ & 29 & $80.5 \%$ & $\begin{array}{l}\text { Very } \\
\text { good }\end{array}$ \\
\hline 9 & $\begin{array}{l}\text { Does the clarity of the learning media } \\
\text { make you more active (feedback) }\end{array}$ & 33 & $91.6 \%$ & $\begin{array}{l}\text { Very } \\
\text { good }\end{array}$ \\
\hline 10 & $\begin{array}{l}\text { Does learning by using programs in the } \\
\text { media make it easier for you to understand } \\
\text { the content of folklore material during } \\
\text { learning activities }\end{array}$ & 29 & $80.5 \%$ & $\begin{array}{l}\text { Very } \\
\text { good }\end{array}$ \\
\hline \multicolumn{2}{|c|}{ Amount Average } & 300 & 83.3 & $\begin{array}{l}\text { Very } \\
\text { good }\end{array}$ \\
\hline \multicolumn{5}{|c|}{ Technical/Appearance Quality } \\
\hline 11 & $\begin{array}{l}\text { How beautiful is the display on the } \\
\text { learning media screen }\end{array}$ & 30 & $83.3 \%$ & $\begin{array}{l}\text { Very } \\
\text { good }\end{array}$ \\
\hline 12 & $\begin{array}{l}\text { How is the legibility of the text of folklore } \\
\text { in the media? }\end{array}$ & 29 & $80.5 \%$ & $\begin{array}{l}\text { Very } \\
\text { good }\end{array}$ \\
\hline 13 & $\begin{array}{l}\text { What is the quality of images, illustrations } \\
\text { and sound in the media. }\end{array}$ & 28 & $77.7 \%$ & Good \\
\hline 14 & $\begin{array}{l}\text { What is the quality of the image color } \\
\text { used in the learning media }\end{array}$ & 27 & $75 \%$ & Good \\
\hline 15 & $\begin{array}{l}\text { How is the composition of the } \\
\text { combination of the colors used in the } \\
\text { media }\end{array}$ & 30 & $83.3 \%$ & $\begin{array}{l}\text { Very } \\
\text { good }\end{array}$ \\
\hline 16 & How easy is the navigation in the media & 29 & $80.5 \%$ & $\begin{array}{l}\text { Very } \\
\text { good }\end{array}$ \\
\hline 17 & How is the use of animation in the media & 28 & $77.7 \%$ & Good \\
\hline 18 & $\begin{array}{l}\text { Are you more interactive with these media } \\
\text { in learning activities? }\end{array}$ & 29 & $80.5 \%$ & $\begin{array}{l}\text { Very } \\
\text { good }\end{array}$ \\
\hline
\end{tabular}




\begin{tabular}{|l|c|l|l|}
\hline Amount Average & 230 & 79.8 & Good \\
\hline Total Amount Average & 530 & 81.79 & $\begin{array}{l}\text { Very } \\
\text { good }\end{array}$ \\
\hline
\end{tabular}

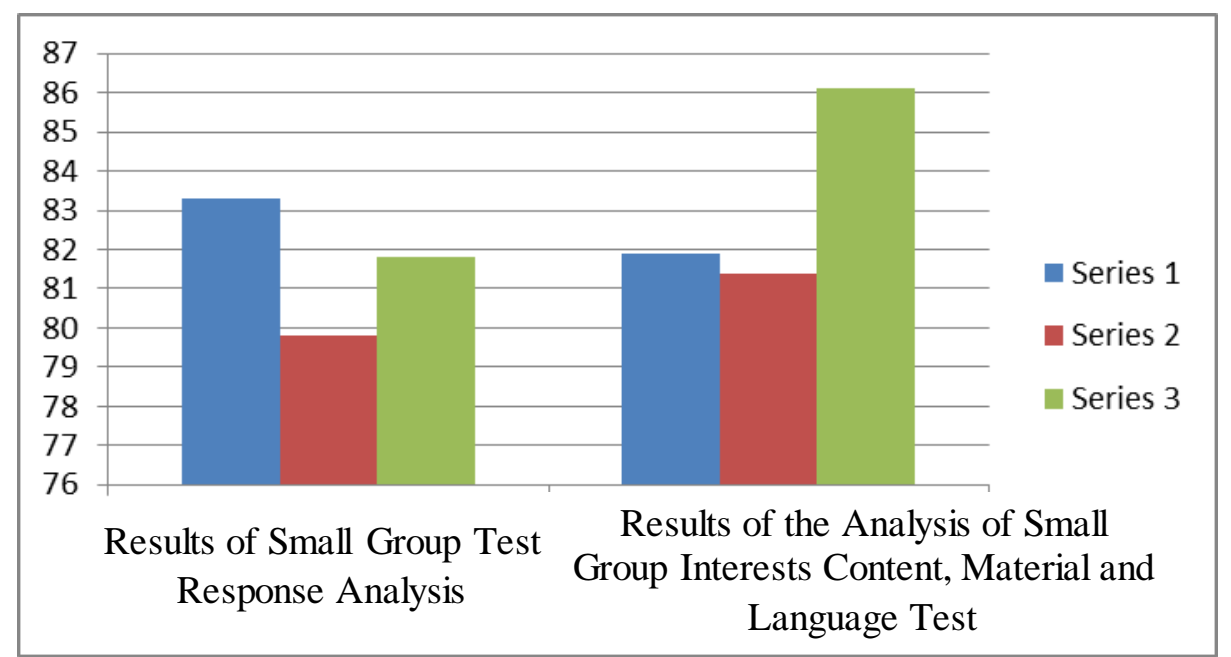

Figure 2. Responses to Small Group Test Results Regarding the Quality of Content and Responses of Class X Students of MAN 2 Tg Pura

The limited field group trial was carried out by testing on a limited scale involving 35 respondents of class XC MANTg. Pura. The test results can be seen in the following table. The data on the results of this limited field group trial is intended to find out some of the weaknesses or obstacles experienced when learning media products write literacybased folklore texts.

Table 3. Results of Limited Field Test Response Analysis

\begin{tabular}{|c|l|c|c|c|}
\hline \multicolumn{2}{|l|}{ No. } & Assessment Indicators & \multirow{2}{*}{ Total } & \multirow{2}{*}{ Criteria } \\
\hline 1 & $\begin{array}{l}\text { Is the material being taught easy for you to } \\
\text { understand }\end{array}$ & 120 & $85.7 \%$ & $\begin{array}{c}\text { Very } \\
\text { good }\end{array}$ \\
\hline 2 & $\begin{array}{l}\text { How is clarity regarding the instructions in } \\
\text { the learning media used }\end{array}$ & 122 & $87.1 \%$ & $\begin{array}{c}\text { Very } \\
\text { good }\end{array}$ \\
\hline 3 & $\begin{array}{l}\text { Is it easy to understand the sentences in the } \\
\text { folk story text can be understood? }\end{array}$ & 134 & $95.7 \%$ & $\begin{array}{l}\text { Very } \\
\text { good }\end{array}$ \\
\hline 4 & $\begin{array}{l}\text { How can it be easier to understand folklore } \\
\text { material through the media }\end{array}$ & 117 & $83.5 \%$ & $\begin{array}{l}\text { Very } \\
\text { good }\end{array}$ \\
\hline 5 & $\begin{array}{l}\text { How is it easier to understand the content, } \\
\text { structure, language and intrinsic value of } \\
\text { folklore through the media more quickly }\end{array}$ & 118 & $84.2 \%$ & $\begin{array}{l}\text { Very } \\
\text { good }\end{array}$ \\
\hline 6 & $\begin{array}{l}\text { How easy is it to understand folklore } \\
\text { material through the media }\end{array}$ & 128 & 91.42 & $\begin{array}{l}\text { Very } \\
\text { good }\end{array}$ \\
\hline 7 & $\begin{array}{l}\text { Is the order of presenting folklore material } \\
\text { in the learning media right? }\end{array}$ & 112 & $80 \%$ & Good \\
\hline 8 & $\begin{array}{l}\text { How is the completeness of the training } \\
\text { activities in the learning media appropriate }\end{array}$ & 121 & $86.4 \%$ & $\begin{array}{l}\text { Very } \\
\text { good }\end{array}$ \\
\hline 9 & Does the clarity of the learning media & 115 & $82.1 \%$ & Very \\
\hline
\end{tabular}




\begin{tabular}{|c|l|c|c|c|}
\hline & make you more active (feedback) & & & good \\
\hline 10 & $\begin{array}{l}\text { Does learning by using programs in the } \\
\text { media make it easier for you to understand } \\
\text { the content of folklore material during } \\
\text { learning activities }\end{array}$ & 121 & $86.4 \%$ & $\begin{array}{l}\text { Very } \\
\text { good }\end{array}$ \\
\hline Amount Average & 1208 & 86.2 & $\begin{array}{l}\text { Very } \\
\text { good }\end{array}$ \\
\hline Technical / Appearance Quality & 122 & $87.1 \%$ & $\begin{array}{l}\text { Very } \\
\text { good }\end{array}$ \\
\hline 11 & $\begin{array}{l}\text { How beautiful is the display on the } \\
\text { learning media screen }\end{array}$ & 124 & $88.5 \%$ & $\begin{array}{l}\text { Very } \\
\text { good }\end{array}$ \\
\hline 12 & $\begin{array}{l}\text { How is the legibility of the text of folklore } \\
\text { in the media? }\end{array}$ & 135 & $96.4 \%$ & $\begin{array}{l}\text { Very } \\
\text { good }\end{array}$ \\
\hline 13 & $\begin{array}{l}\text { What is the quality of images, illustrations } \\
\text { and sound in the media. }\end{array}$ & 118 & $84.2 \%$ & $\begin{array}{l}\text { Very } \\
\text { good }\end{array}$ \\
\hline 14 & $\begin{array}{l}\text { What is the quality of the image color used } \\
\text { in the learning media }\end{array}$ & $\mathbf{2 1 9 0}$ & $\mathbf{8 6 . 9}$ & $\begin{array}{l}\text { Very } \\
\text { good }\end{array}$ \\
\hline 15 & $\begin{array}{l}\text { How is the composition of the combination } \\
\text { of the colors used in the media }\end{array}$ & 118 & $84.2 \%$ & $\begin{array}{l}\text { Very } \\
\text { good }\end{array}$ \\
\hline 16 & $\begin{array}{l}\text { How easy is the navigation in the media } \\
\text { good }\end{array}$ & 129 & $92.1 \%$ & $\begin{array}{l}\text { Very } \\
\text { good }\end{array}$ \\
\hline 17 & $\begin{array}{l}\text { How is the use of animation in the media } \\
\text { Total Amount Average }\end{array}$ & 113 & $80.7 \%$ & $\begin{array}{l}\text { Very } \\
\text { good }\end{array}$ \\
\hline 18 & $\begin{array}{l}\text { Are you more interactive with these media } \\
\text { in learning activities? }\end{array}$ & 123 & $87.8 \%$ & $\begin{array}{l}\text { Very } \\
\text { good }\end{array}$ \\
\hline Amount Average & $\mathbf{9 6 . 2}$ & $\begin{array}{l}\text { Very } \\
\text { Ame }\end{array}$ & & \\
\hline
\end{tabular}



Figure 3. Analysis Results of the Response to the Media and the Quality of the Content on the Media in the Limited Field Group Test 
The diagram above shows that the assessment of the results of the response analysis regarding the quality of the learning media obtained an overall average of 86.9 which includes technical / display quality getting an average of 96.2, and the quality of the material obtaining an average result of 86.2. The comparison between the quality of the content in the learning media in terms of content such as 85.1 in terms of interest in terms of material obtained 88.8 results and in language obtained 84.7 with the overall quality of the media and the content on the criteria "Very Good".

The conclusion from the results of the responses of class XC MAN $2 \mathrm{Tg}$. Pura, namely a learning media to write literacy-based folklore texts that have been devel- oped to be feasible and meet the needs with the overall criteria of "Very Good". This means that the learning media developed has increased development and can meet the demands of learning needs.

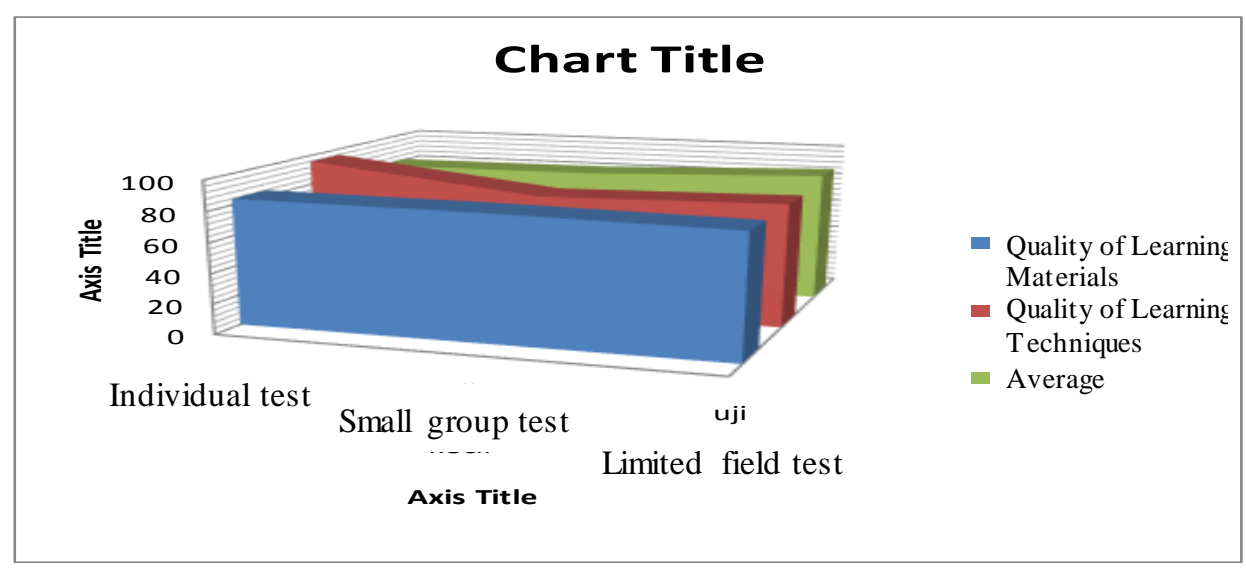

Figure 4. the results of each test

The results of the effectiveness of using learning media developed on literacy-based folklore text material in class X MAN Tg. Pura using learning media is in the "very good" category. The learning outcomes can be seen from the average value obtained by students after using the developed learning media.

In the pretest and posttest tests carried out in XC class at the testing stage of learning using interactive multimedia in learning to write literacy-based folklore without any guidance from the teacher, the score was 66.57 in the pretest class. However, in the posttest class using interactive multimedia on literacy-based folklore writing learning with guidance from the teacher, the results obtained were 81.14 with a significance difference of $14.57 \%$.

Thus the results of the effectiveness of using learning media to write literacy-based folklore texts have a significant impact with a significance difference of $14.57 \%$. The difference in the average score of students before and after using the developed learning media. Shows an increase in student learning outcomes towards the use of the developed media, which can be identified from the average results in the pretest and posttest classes.

Seeing the increase in student learning outcomes described above, it can be concluded that the learning media developed is suitable for use in learning to improve student learning outcomes.In line with Arda's research (2015) in his journal "Development of computer-based interactive media" and Yanti et al (2014) in his journal "The Effect of Image Media Use on the Ability to Write People's Poetry of Class VII Junior High School Students 6 Jambi City Academic Year 2017/2018". Whereas the results of the analysis carried out, the average value of the experimental class taught using image media was 
76.17 for the pre-test and 78.73 for the post-test, which was greater than the class average value. control 71.17 for the pre-test and 72.91 for the post-test.

This is also in line with the research of Rita and Julaga Situmorang (2014) in their journal of developing interactive multimedia learning based on the internet in English lessons, which states that $82 \%$ of students do not know interactive multimedia learning, $89 \%$ of students do not use interactive multimedia learning in the learning process, and $80 \%$ students need interactive multimedia learning. So it is in line with the opinion of Rita and Julaga Situmorang (2014) that it requires Adobe Flash CS6 learning media.

Furthermore, it is commensurate with the research of Wahyuni et al. (2017) in his journal "Development of E-Learning-Based Interactive Multimedia Modules at Principal Size and Units in SMA" Vol 6. Effectiveness is measured through posttest activities at the end of learning. Based on the results of the students' posttests, it can be seen that the average value obtained is 67.26 so that based on the aidience validation criteria the value can be used with small revisions.

This is also in accordance with the opinion of Kemp and Dayton (in Rusman, 2013: 168) which states that the use of learning media has a contribution to the development and improvement of learning, namely as follows: (1) delivery of more standardized learning messages, (2) learning can be more interesting, (3) learning becomes more interactive by applying learning theory, (4) learning implementation time can be efficient, (5) learning quality can be improved; (6) learning can take place whenever and wherever needed, (7) increasing students' positive attitudes towards the learning material and process, and (8) the teacher's role changes to a more positive direction.

There are several theories on the use of instructional media, one of which is Dale's Cone of Experience theory (Dale, 1969). Dale estimates that learning outcomes obtained through the visual sense are around $75 \%$, the sense of hearing is around $13 \%$, and the other senses are around 12\% (Rusman, 2013: 165). This is what causes the use of learning media to be very important to use in learning activities.

The use of instructional media has a positive impact on students' ability to write folklore texts. As stated by Hooper (in Siyamta, 2013: 2) states that multimedia as a presentation medium is different from multimedia as a learning medium. Presentation media does not require users to actively interact in it; even if there is interactivity, it is covert interactivity.

\section{Conclusion}

The results of the feasibility of developing literacy-based folklore text learning media were declared feasible because all the results of the assessment were in the "very good" category. The results of the validation by the material experts were stated to be "very good" with all aspects of the assessment getting an average of 85.4, and the results of the validation by the media design experts were declared "very good" with all aspects of the assessment getting an average of 85.3 stated "very good". Then the results of the response of Indonesian language teachers with an average of 85.5 on the "very good" criteria. The results of individual trials were stated as "very good" with an average percentage of 81.01. The results of the small group trial were stated "very good" with an average percentage of 81.79 . And the results of limited field trials were declared "very good" with an average percentage of 86.9 .

The results of students' learning ability in writing literacy-based folklore texts after using the developed learning media were in the "very good" category with an average value of 81.14 and the average value before using literacy-based folklore text learning 
media of 66, 57 which is in the "good" category. This proves that student learning outcomes are higher after using literacy-based folklore text learning media with a significance difference of $14.57 \%$.

\section{References}

Abidin, Y. (2014). Desain Sistem Pembelajaran dalam Konteks Kurikulum 2013. Bandung: PT Refika Aditama. . (2015). Pembelajaran Multiliterasi. Bandung: PT Refika Aditama

Ann Hogue dan Alice Oshima. 2007. Introduction Academic Writing. USA. Longman

Ansyori, H. R. (2016). "Menumbuhkan Minat Baca Sebagai Upaya Meningkatkan Kualitas Sumber Daya Manusia". http//imadiklus.com/menumbuhkan minatbacasebagai-upaya-meningkatkan-kualitas-sumber-daya-manusia/. Download on 10 September 2018

Arianto.2017. Pengembangan Bahanajar Menulis Teks Eksposisi Berbasis Literasi Pada Siswa Kelas X SMA. Tesis tidak diterbitkan. Medan: Program Pascasarjana Unimed

Azhar A. (2009). Media pembelajaran. Jakarta: PT Rajawali Pres.

Beach, R.W. \& Marshal, J.D. (1991). Teaching literature in the secondary school. Orlando: Harcourt Brace Javanovich, Inc.

Borg, W. R. \& Gall, M. D. (1983). Educational research: an introduction $\left(^{4^{\text {th }}}\right.$ ed). New York: Longman.

Caldwell, J. S. (2008). Comprehension assesment: a classroom guide. New York: The Guilford Press.

Danandjaja, J. (2007). Foklor Indonesia: Ilmu gossip, dongeng, dan lain-lain. Jakarta: Pustaka Utama Grafiti.

Darmawan, D. (2014). Inovasi pendidikan: pendekatan praktik teknologi multimedia dan pembelajaran online. Bandung: PT Remaja Rosdakarya.

Dick, W. Carey, L. \& Carey, J. O. (2005). The systematic design of instruction $\left(6^{\text {th }} e d\right)$. New York: Addison-Wesley Educational Publishers Inc.

Drabenstott, K.M. (2003). Interactive multimedia for library-user education. Portal Libraries and the Academy. Baltimore

Dalman. (2014). Keterampilan menulis. Jakarta : raja Grafindo Persada

Gary Woolley.(2014).Developing Literacy in the Primary Classroom. SAGE Publications Ltd. California

Gillet, J. W. dan Charles T. (1986). Understanding reading problems: assesment, and instruction second edition. USA: Little, Brown and Company.

Goran, M.I. \& Reynolds, K. (2005). Interactive multimedia for promoting physical activity (IMPACT) In Children. Obesity Research

Green, T. D. \& Brown, A.( 2002). Multimedia projects in the clasroom. United States of America: Corwin Press, Inc.

Hamilton. Mary. (2005). Adult Literacy as Social Practice. New York: Routledge is an imprint of the Taylor \& Francis Group

Harbarth, S. (1996). The educational technology handbook; a comprehensive guide process and products for learning. New Jersey: Edicational.

Harris, A. J. and Sipay, E. R. (1980). How to increase reading ability. New York: Longman.

Holub, R. C. (1984). Reception theory: a critical introduction. London and New York: Methuen. 
Hassan. Mahmoud.(2015). Suggested Strategy for Developing Critical Literacy. International Journal of Humanities and Social Science. www.ijhssnet.com

Ivers, K.S \& Barron, A.E. (2010). Multimedia projects in education desaigning, producing, and assessing. California: Libraries Unlimited An Imprint of ABCCLIO, LLC.

Izmirli, K. \& Kurt, A.A. (2016). Effects of modality and pace on achievement, mental Effort, and positive affect in multimedia learning environments. Journal of educational computing research.

Jhon, Foster. (2008). Effective Witing Skills for Public Relations. London and Philadelphia. Kogan Page

Kusmayadi, dkk. (2017). Pengembangan Multimedia Cerita Rakyat Sebagai Penumbuhan Karakter Siswa. Jurnal Pendidikan: Teori, Penelitian, dan Pengembangan

Kusyani, Diah. (2017). Pengembangan Multimedia Interaktif untuk Pembelajaran Membaca Sastra Lama berdasarkan Teori Resepsi bagi Siswa SMP. Jurnal UNY

Lorrie, Blair. (2016). Writing a Graduate Thesis or Disertation. USA. Sense Publisher

Mayer, R. E. (2009). Multimedia learning. Yogyakarta: Pustaka Pelajar.

Marsellaa, E., Putri, D., M. (2020) Folklore as Ethnic Embodiment Bias: Value Analysis on Karo Folklore. Budapest International Research and Critics Institute-Journal (BIRCI-Journal), 2619-2628.

Mitchell, D. (2003). Children's literature, an invitation to the world. Boston: Ablongman.

Muhsin Kalida \& Moh. Mursid. (2015). Gerakan Literasi Mencerdaskan Negeri. Yogyakarta : Cakruk Publishing.

Muntihanah. (2016). Cerita Ebhi Dan Khandei Sebagai Bahan Bacaan Anak. (Ebhi dan Khandei Story as Reading Material for Children) Jurnal Ilmiah Metasastra

Nainggolan, N., C., Rosliana. (2020). The Development Of Literacy Reading Books of North Sumatera Fairy Tale For V Grade Students at Elementary School. Britain International of Linguistics, Arts andEducation(BIoLAE) Journal, 724-737.

Nurgiyantoro, Burhan. (2010). Sastra Anak: Pengantar Pemahaman Dunia Anak. Yogyakarta: Gadjah Mada University Press.

Nunung Fatimah. (2017). Pengembangan Buku Cerita Rakyat Bima Berbasis Kearifan Lokal (Sebagai Penunjang Gerakan Literasi). Jurnal Ilmiah, NOSI

Nurhasanah , Prita, Diah. (2016). Perbedaan Hasil Belajar Menulis Narasi Reproduksi Antara Siswa Yang Memperoleh Model Multiliterasi Transformasi Dan Model Moody (Penelitian Kuasi Eksperimen Pada Siswa Kelas Iv Sdn Mekarsari Dan Sdn Cibiru 08 Kecamatan Cileunyi Kabupaten Bandung).

Palelupu Neo Davik. (2014). Pengembangan Media Pembelajaran Berbasis Adobe Flash Cs5 Pada Mata Diklat Gambar Teknik Di Kelas X Tpm Smk Krian 1 Sidoarjo. Jurnal JPTM

Passerini, K. (2007). Performance and behavioral outcomes in technology-supported learning: the role of interactive multimedia. Journal Of Educational Multimedia And Hypermedia; Norfolk

Philip. R. (1997). The developer's handbook to interactive multimedia: a practical guide for educational applications. London: Kogange.

Rahardjo, Turnomo dkk. (2013). Literasi Media dan Kearifan Lokal "konsep dan aplikasi”.'Mata Padi Pressindo

Rafiek. (2010). Teori sastra kajian teori dan praktik. Bandung: Refika Aditama

Resmini, Novi._. Orasi Dan Literasi Dalam Pengajaran Bahasa.____ (online),____ (http://file.upi.edu/direktori/fpbs/jur._pend._bhs._da 
n_sastra_indonesia/196711031993032novi_resmini/orasi_dan_literasi_dalam_pe ngajaran_bahasa.pdf. Access on 26 januari 2019).

Rismawaty.(2017). Perkembangan Sejarah Sastra Indonesia. Banda Aceh. Bina Karya Akademika

Rivers, W.R. \& Temperley, M.S. (1978). A pratical guide to the teaching of English as a second or foreign language. Oxport: Oxport Unversity Press.

Ruddell, M.R. (2005). Teaching content reading and writing. Amerika: Jhon Wiley \& Sons, Inc.

Samsuyurnita. (2012). Keterampilan Menulis. Medan. Umsu

Semi, Atar. (1988). Anatomi Sastra. Padang: Angkasa Jaya

Sihabudin, Ahmad. (2013). Literasi Media Memberdayakan Kearifan Lokal. Jurnal Communication

Siyamta.(2013). Pengembanagana Multimedia Pembelajaran Interaktif. Media Pembelajaran : Media \& Produksi. Malang

Sukardjo. (2006). Kumpulan materi evaluasi pembelajaran. Yogyakarta: Program Pascasarjana Universitas Yogyakarta.

Suyanto, M. (2005). Multimedia alat untuk meningkatkan keunggulan bersaing. Yogyakarta: Andi.

Sugiarto, E. (2015). Mengenal dastra lama: jenis, defenisi, ciri, sejarah, dan contoh. Yogyakarta: Andi Offset.

Stephen, B. Kucher. (2014). Dimensions of Literacy A Conceptual Base for Teaching Reading and Writing in School Settings. London. Routledge

Syahrani, Agus. (2013). Budaya Lisan Vs Budaya Literasi Mahasiswa Melayu: Implikasinya Pada Model Pembelajaran Mahasiswa. Wacana Etnik,(online), Jurnal Ilmu Sosial dan Humaniora

Tarigan, H,G. (2013). Menulis sebagai Suatu Keterampilan Berbahasa. Bandung. Angkasa

Teoh, B.S.P., \& Neo, T.K. (2007). Interactive multimedia learning: students' attitudes and learning impact in an animation course. The Turkish Online Journal of Educational Technology

Tomlinson. (2014). Developing Materials for Language Teaching. USA. Bloomsbury Publishing Plc

Tompkins, G. E. (1997). Literacy for the $21^{\text {st }}$ century: a balanced approach. Amerika: Pearson.

Wood, R. (2011). Kalila dan Dimna: fabel tentang pertikaian dan intrik. Jakarta: PT Gramedia.

Yohana, et al. (2019). The Development of Instrument of Reading Literacy Assessment on Indonesian Language Learning in Quality Medan University. Budapest International Research and Critics in Linguistics and Education (BirLE) Journal, 372-387.

Yunita, Reni. (2017). Pengembangan Multimedia Adobe Flash Cs5 Berbasis Stad Sebagai Media Pembelajaran Ipa Pada Pokok Bahasan Sistem Gerak Pada Manusia Untuk Smp/Mts. Skripsi

Zhang, D. \& Zhou, L. (2003). Enhancing e-learning with interactive multimedia. Information Resources Management Journal. 